Historic, Archive Document

Do not assume content reflects current scientific knowledge, policies, or practices. 



\section{2,23}

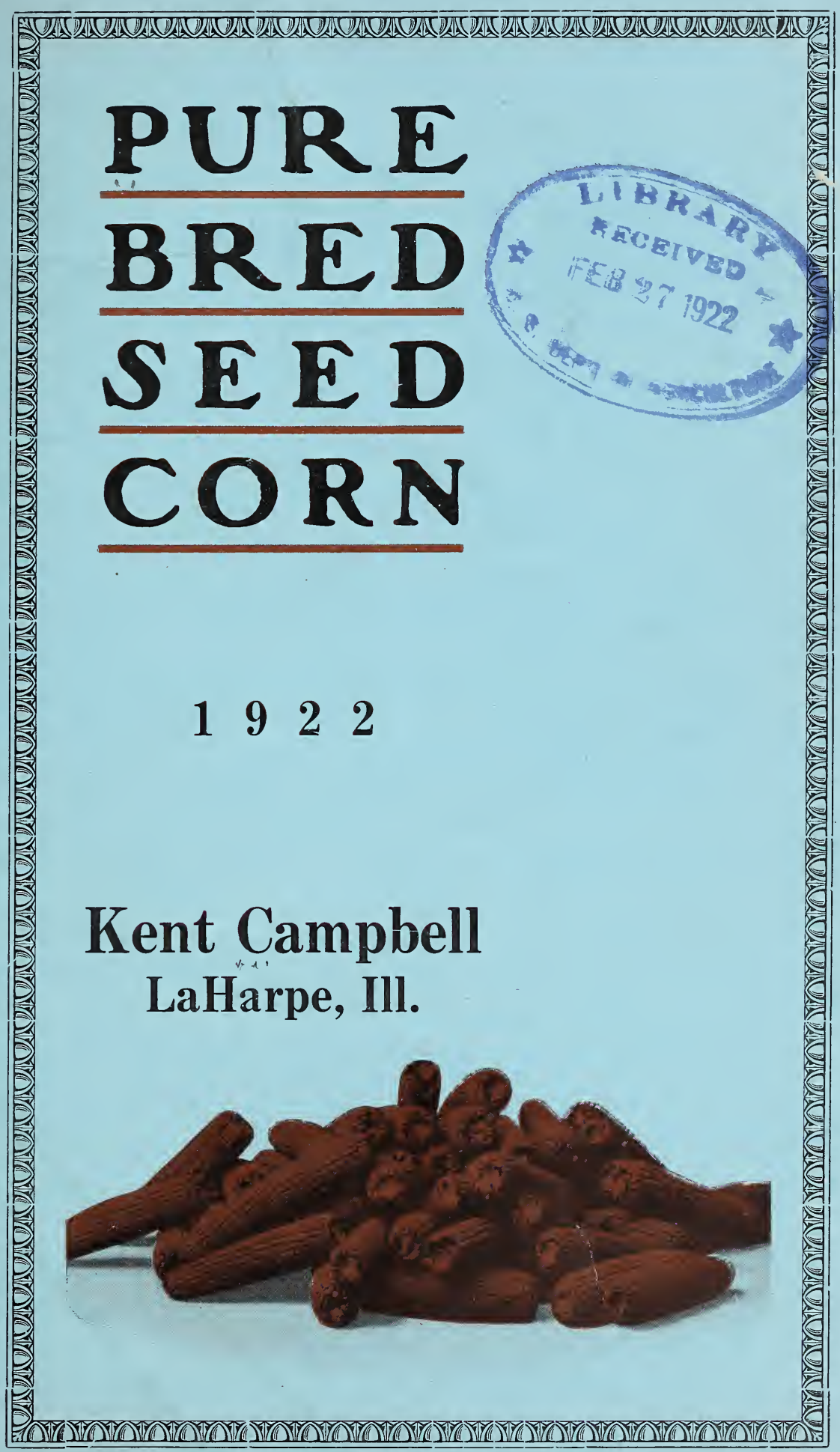




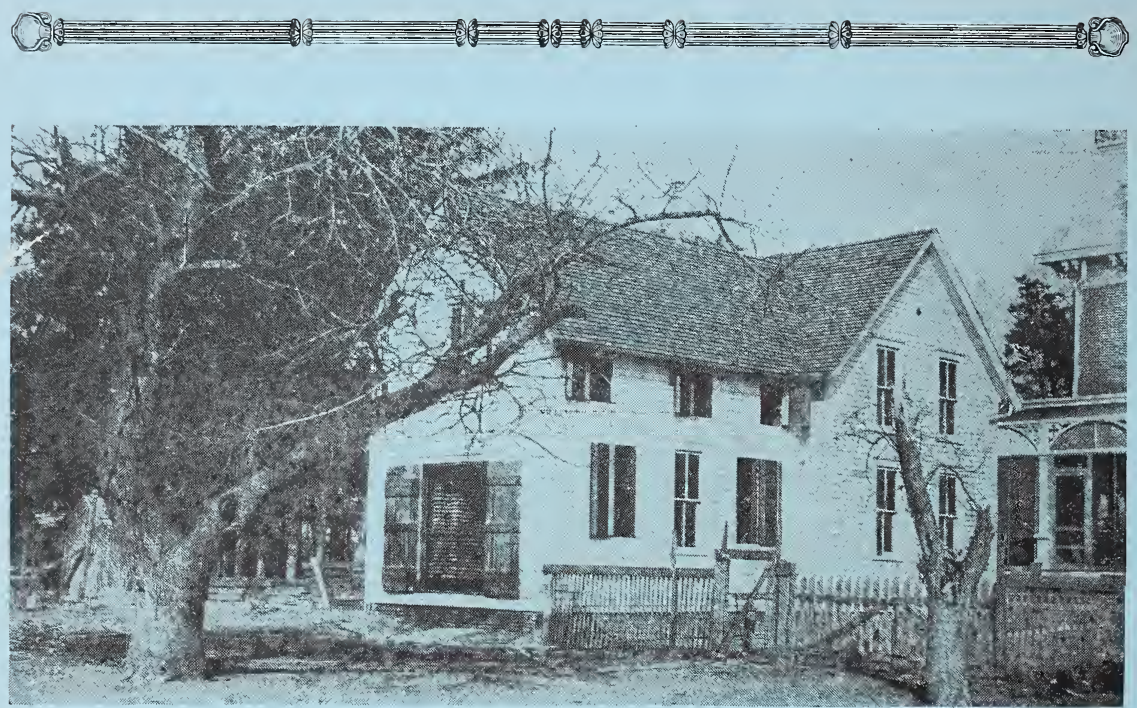

The Building We Formerly Used.
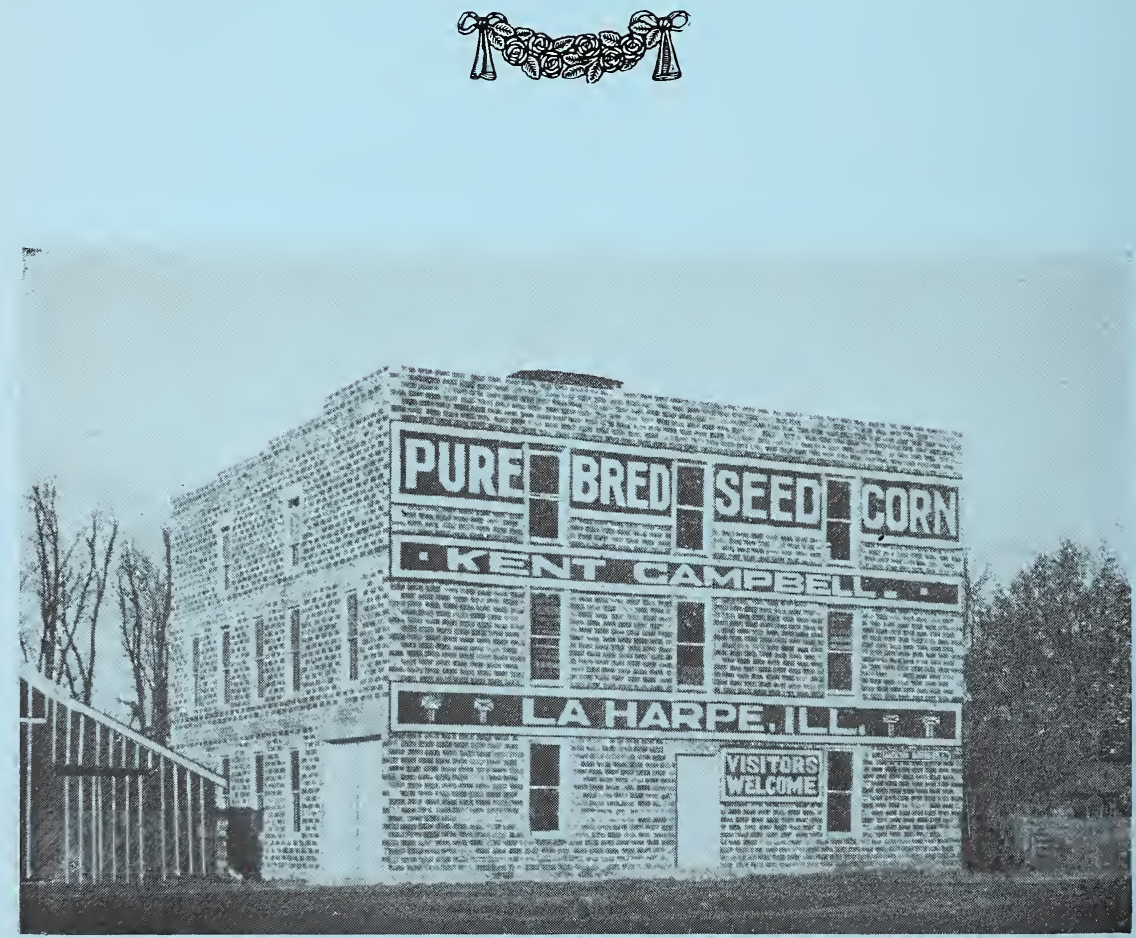

The Seed House Where We Dry and Store Our Seed Corn.

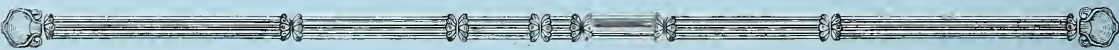




\section{foreward}

\section{To Our Friends and Customers:}

Greetings and best wishes for a happy and prosperous Nineteen Twenty-two.

Another year has rolled around, and we have come to issue another catalog that you may know we are ready to serve you again with Quality Farm Seeds. From the mistakes of the past we learn lessons which are a help to us in our future work, and each year we see an improvement in our corn work. Our aim is to give our customers seed that will grow the greatest number of bushels of quality corn per acre.

Market prices of seeds are much lower this year and we have reduced prices accordingly and they are on a pre-war basis that you can afford more than ever to buy the best of seed.

Your order this year will receive our usual careful attention.

Thanking you for your splendid patronage and wishing you success in every way, we are

Very truly yours;

KENT CAMPBELL. 


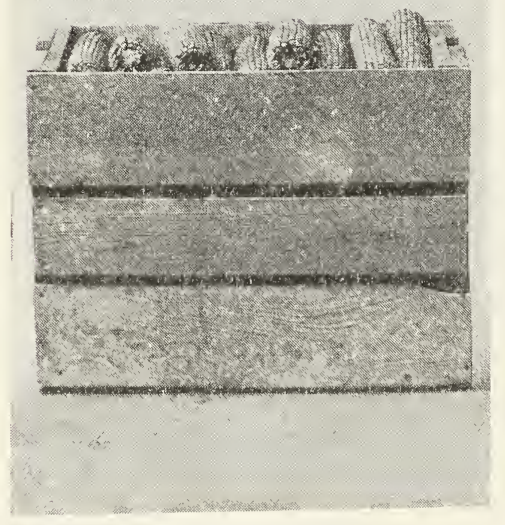

Crate of Seed Corn.

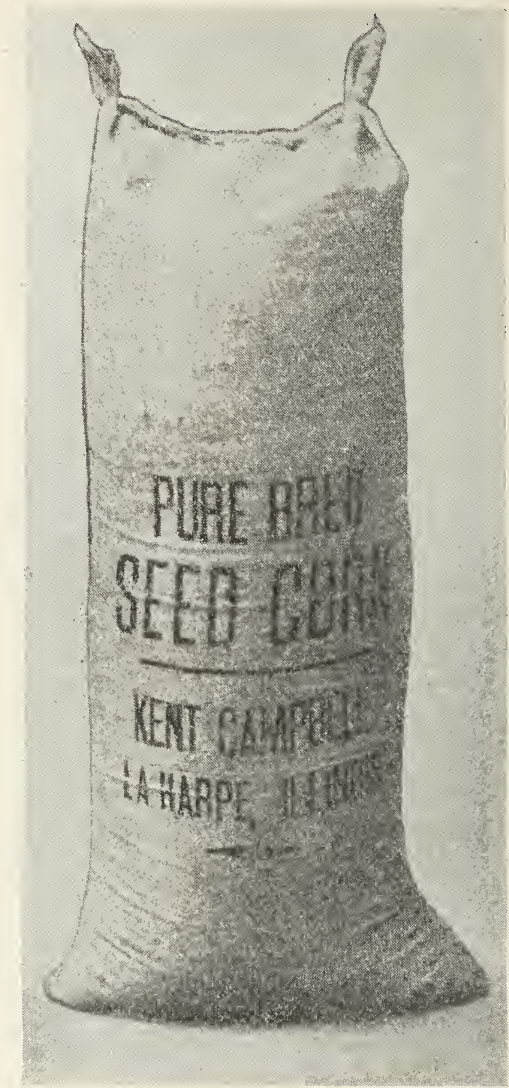

Sack of Seed Corn.

\section{Growing and Handling Our Seed Corn}

W ${ }^{\mathrm{E}}$ personally oversee the selection, storage and preparing for shipment of all the Seed Corn we handle. We live on the farm and grow the most of our seed on our own farms. You may have wondered if we grow all the corn we handle. No. we grow all we can, and have some of our neighbors, who are good corn growers, furnish the balance for us. We think the farm is the place for the Seed Corn grower to live. We have had thirteen years' experience in growing, selecting and handling Seed Corn, and it is our aim to give our customers the benefit of our experience and knowledge to the very best of our ability. We use the very best seed obtainable to plant the corn from which our seed corn

We invite you to Come and Visit us and see for yourself how we Handle our Corn. 
is picked. Our corn is grown in the best, soil we have, and no pains or expense are spared.

In the fall we go down each row of corn with a sack and pick the earliest maturing ears for seed. When the sack is full, it is emptied out alongside of the down row, and the picked corn is hauled direct to the seed house, where it is again sorted before it is placed on the racks. The culled corn is thrown out and used for feeding purposes, while the best ears are placed on the racks to dry. The corn is left on the racks until it is taken down for testing $r, r$ to fill orders. At that time they are taken down and carefully examined, and either crated as ear corn or butted, tipped, shelled and graded ready to plant. Nearly all the seed we handle is shelled and graded ready to plant.

We want to emphasize the fact that our shelled seed has been carefully examined, and butted and tipped by hand, before it is shelled and graded. Some Seed Corn firms grade out the butts and tips and can sell their seed cheaper. It is our desire to put out Seed Corn of the very' best, so we butt and tip all our corn by hand. We have a large furnace in the seed house to dry the corn and a fire is kept going all winter to prevent freezing, as extreme cold always tends to weaken the vitality. The seed house has three stories with spaces between the boards in the floor so the air can circulate freely. There are forty-seven doors and windows which are opened on drying days. On cloudy, damp days these openings are closed so that the fire in the furnace will dry the corn.

Each year we conduct a breeding plot which is more fully discussed on another page. It is our aim to develop a high-yielding strain of corn. This year we conducted a Corn Root Disease plot co-operating with the Hancock County Farm Bureau. This plot is more fully described on another page. The seed we offer for sale was grown from corn selected to be disease free.

It costs $\$ 1.00$ per acre to seed Oats, $\$ 1.25$ per acre to seed Wheat, and ONLY $45 \mathrm{c}$ per acre to plant Campbell's early selected rack dried Corn.

\section{TESTIMONIALS.}

Mr. Kent Campbell, LaHarpe, Ill.

Warsaw, Ill., Dec. 17, 1921.

Dear Sir: I am well pleased with the seed I bought of you. My corn is the best in the neighborhood. I have a fine lot of seed corn, as I was very careful when gathering it. I also liked the oats fine. When you find out the prices on seed corn next year, will you kindly let me know. Yours truly,

I. P. DAVIDSON.

Mr. Kent Campbell, LaHarpe, Ill.

Bushnell, Ill., Dec. 28, 1921.

Dear Sir: I am well pleased with the Reid's Yellow Dent seed corn I bought of you last spring. It made from three to five bushels more per acre than my own seed made. What is your common Red Clover seed worth? And your Soy Beans? Awaiting an early reply, Yours resp.

B. M. ROGERS. 


\section{From Field}

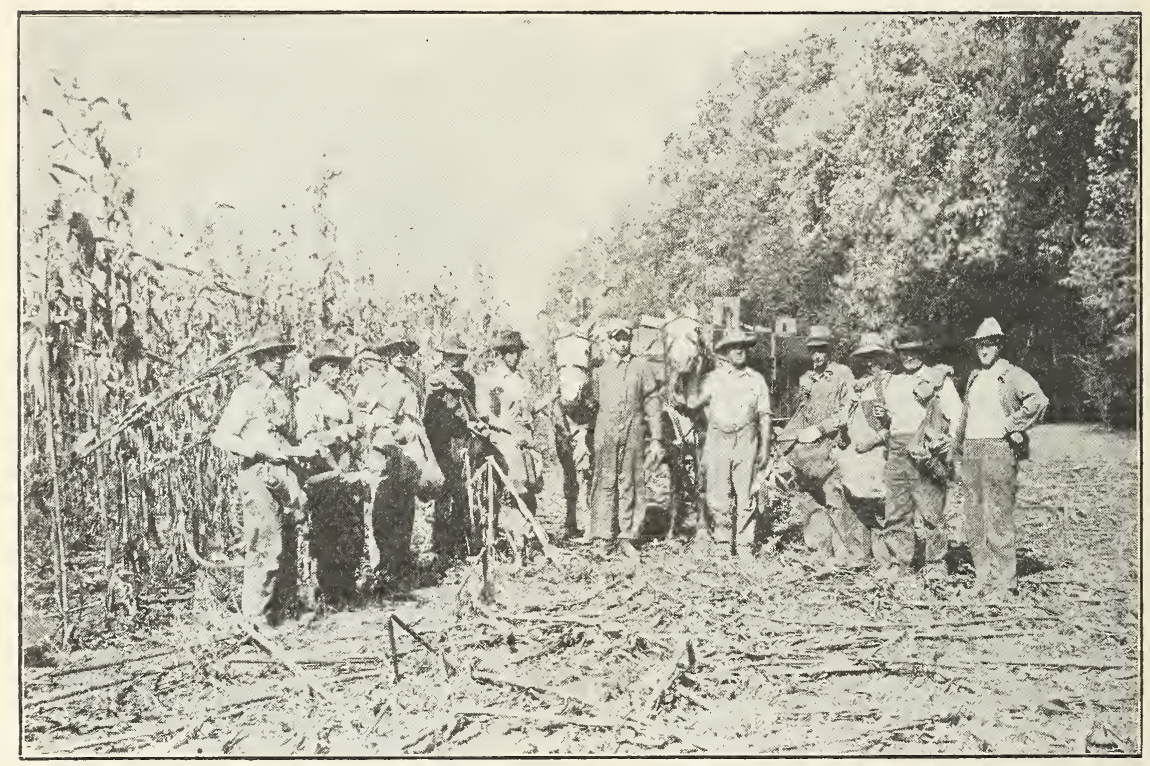

\section{To Rack}

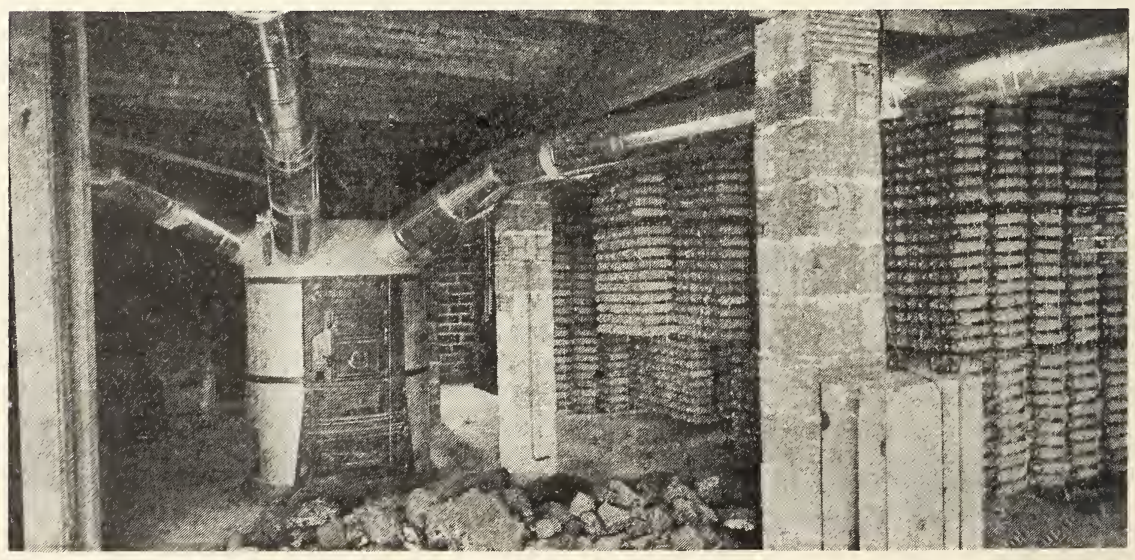

All Shelled Seed butted, tipped and graded. 


\section{Improved Reid's Yellow Dent}

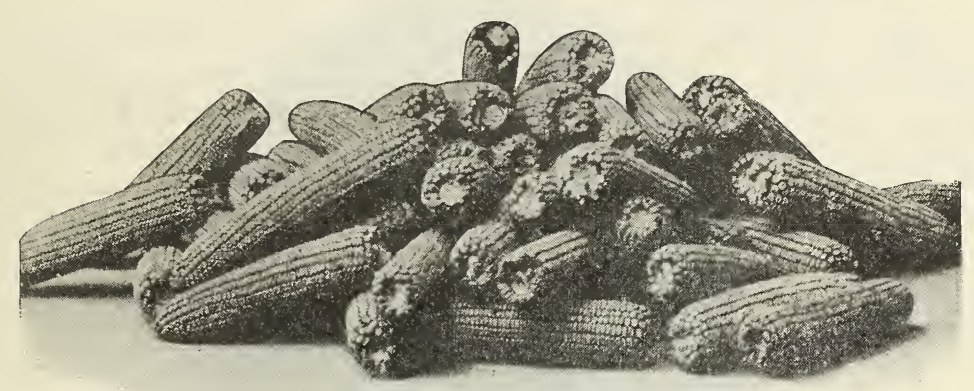

L

IGHT golden in color, ears from 9 to 12 inches long and 7 to 8 inches in circumference. No space between rows, which range from 16 to 20 . The cob is almost completely covered with corn. Very small shank; ears run very uniform in size, color and shape. Shells from 88 to 90 per cent of corn. Kernels are moderately dented or rough and fully one-half inch deep. Cob red and medium in size. This corn is very easy to husk. Stalks from 9 to 12 feet and an abundance of foliage, making it popular for fodder. This corn will get out of the way of frost in from 105 to 115 days, according to location, soil and season.

\section{Prices.}

Sack Picked and Hung Between Sept. 21 and Oct. 5.

Butted and Tipped by hand, Shelled and graded ready to plant. One peck, $\$ 1.00$. One-half bushel, $\$ 1.75$. One bushel or more, $\$ 3.00$.

Sacks free.

EAR CORN, $\$ 3.50$ per bushel in crates.

Selected at early husking and in the seed house before Nov. 15.

Butted and tipped by hand. Shelled and graded ready to plant.

One peck, 75c. One-half bushel, $\$ 1.50$. One bushel or more, $\$ 2.50$ per bushel. Sacks free.

EAR CORN, $\$ 3.00$ per bushel in crates.

No order accepted for less than one bushel in ear.

Mr. Kent Campbell,

LaHarpe, Ill.

LaHarpe, Ill., Dec. 20, 1921.

Dear Sir: Just finished shucking corn. Fifty-four acres Reid's Yellow Dent made 3,930 bushels. Ten acres of 90 -day corn made 550 bushels. Good stand and good quality for this year.

Yours truly,

B. E. RILEY. 


\section{Boone or Johnson County White}

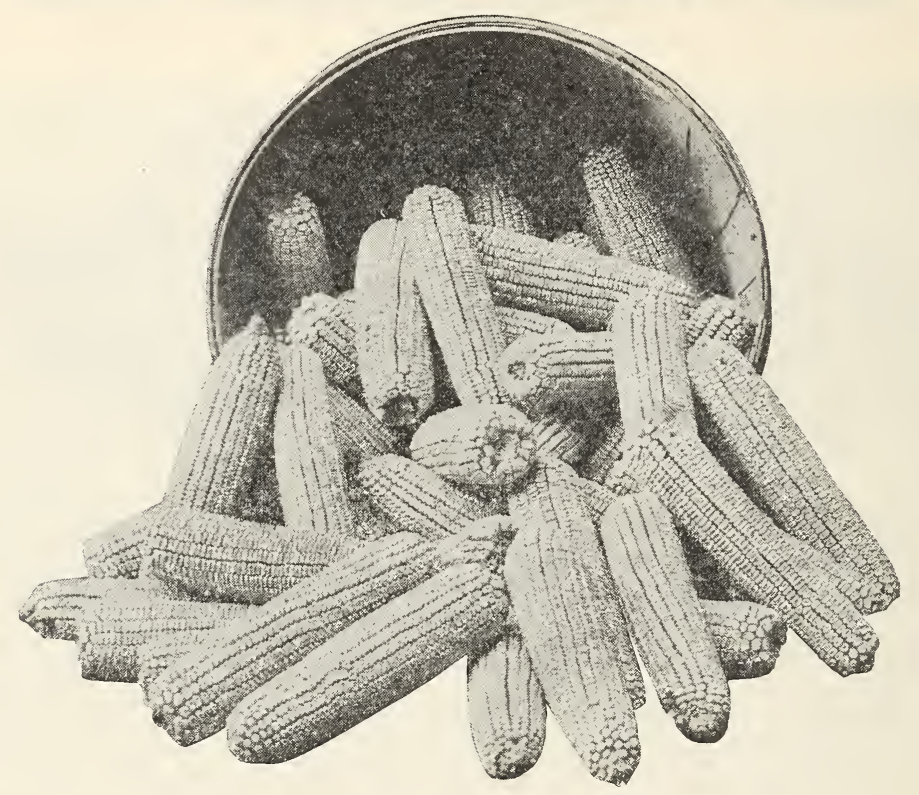

7 HIS corn was originated by Mr. James Riley, of Boone county, Indiana. The shape of the ear is slightly tapering, length to 10 inches and 7 to $71 / 2$ inches in circumference. The kernel is a large, broad, deep kernel approaching the broadly rounded wedge type. The dent is moderate to deep creased with slightly roughened projections. This corn is one of the largest varieties of white corn there is and requires a longer season to mature than the Silvermine.

This corn is a good yielder and is too well known by all corn raisers to need much description.

Price. Picked in a sack, hung in a rack, between September 21 and October 5. Shelled and graded ready for planting. One peck, $\$ 1.00$. One-half bushel, $\$ 1.75$. One bushel, $\$ 3.00$. Sacks free. Ear corn in one bushel crates, $\$ 3.50$ f. o. b. LaHarpe. No orders accepted for less than one bushel in the ear.

Mr. Kent Campbell,

LaHarpe, Ill.

Blandinsville, Ill., Dec. 23, 1921.

Dear Sir: Received your let:er, and in reply will say I certainly had some fine corn, well filled ears, and made sixty-five bushels per acre.

I was well satisfied, and when needing seed will see you.

Thanking you,

RAYMOND GEORGE.

Good Seed builds your farm up; poor seed runs your farm down. 


\section{Good Standard Leaming}

$\mathbf{L}$

EAMING corn was originated by J. S. Leaming, of Ohio, and improved by J. S. Chester and L. F. Maxey, Illinois breeders. It is deep golden yellow, ears 8 to 11 inches long, and 7 to 8 inches in circumference, with 16 to 22 rows of kernels of medium rough type. An excellent corn for forage or silage on account of large amount of foliage. Matures in 105 to 115 days.

Prices Picked in a sack, hung in a rack between Sept. 21 and Oct. 5. Shelled and graded ready for planting. One peck, $\$ 1.00$. One-half bushel, $\$ 1.75$. One bushel, $\$ 3.00$. Sacks free. Ear corn in bushel crates, $\$ 3.50$ f. o. b. LaHarpe.

Mr. Kent Campbell,

Bloomsdale, Mo., Dec. 11, 1921.

LaHarpe, Ill.

The seed corn we got from you last spring was the best I have tried for years. I have been using your corn for the last three seasons with best results. Never had to replant any corn last spring, and had a splendid stand. Raised my best crop this season since farming on this place. Would use your seed corn again if I wasn't leaving the farm. Will frankly recommend your seeds to anyone.

Respectfully yours,

CHAS. F. HOGENMILLER,

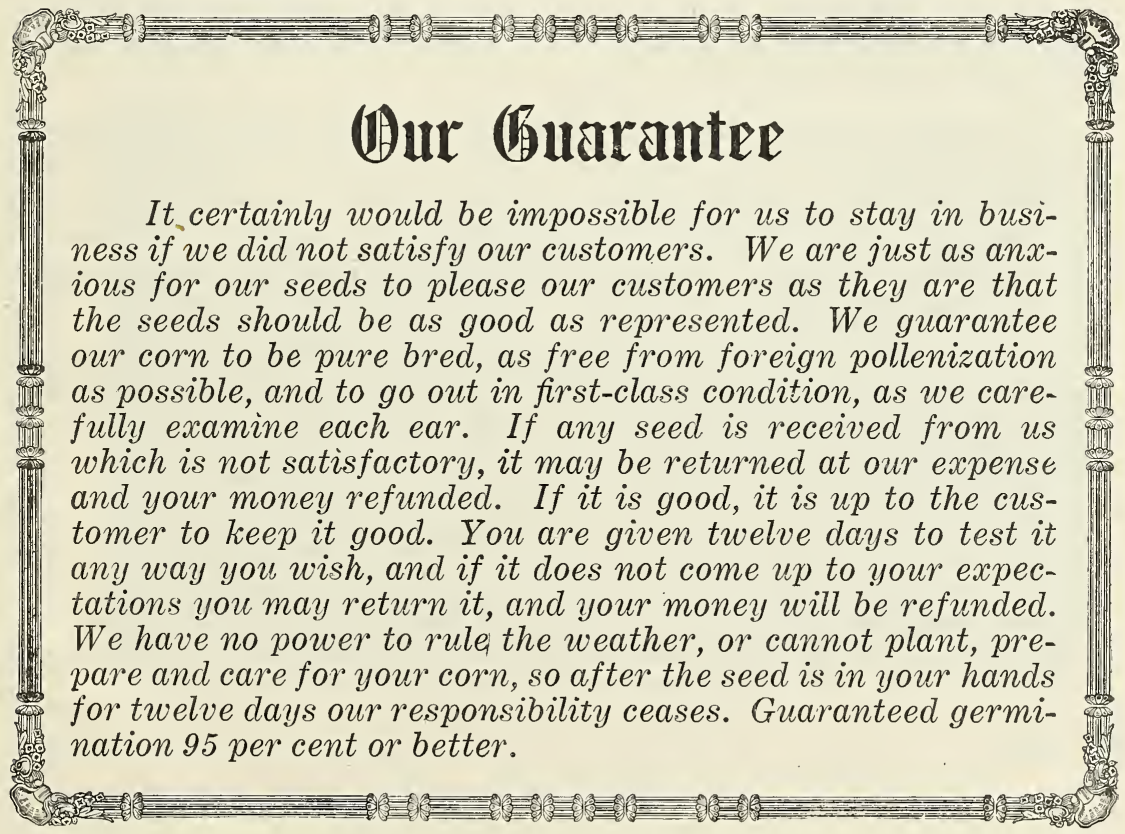

Don't Sow cheap seed of any kind. Too high priced. 


\section{Early Corn for Hogging Down}

$\mathrm{E}$

VERY farmer should plant some early corn each year for early feed. The demand for early corn is increasing each year, for the practice of hogging down corn is growing more popular. It saves considerable expense in husking and the hogs seem to do better than when fed by hand.

\section{EARLY YELLOW.}

An excellent medium early corn, matures in about 100 to 105 days, and is medium rough type. Ears, 8 to 10 inches long and 7 to 8 inches in circumference. This corn yielded 50 bushels per acre for us this year.

Price: Picked in sack, dried on a rack, shelled and graded ready for planting. One peck, $\$ 1.00$. One-half bushel, $\$ 1.75$. One bushel, \$3.00. Sacks free. Ear corn in bushel crates, $\$ 3.50$ f. o. b. LaHarpe.

\section{BREEDING PLOT WORK.}

Each year an ear-to-row breeding plot is conducted in connection with our seed corn work. It is our aim to develop a high yielding strain of corn with early maturity. We started with 306 ears of the best strains of corn we could find, tested them out in a test plot, planting 35 hills from each ear. Each row was harvested and weighed separately. It was found the yields varied from 40 to 104 bushels per acre.

The next year the remnants from the best 48 ears were planted in a breeding plot and alternate rows detassled. Four ears from 12 of the highest yielding rows, a total of 48 ears will be selected for the next year's work. It is found that the rows with lots of barren stalks are poor yielders. By eliminating the barren stalks we increase the yield.

We are selecting our seed on the utility type winning second prize on fifty ears at the Galesburg Corn Show last year. We have several testimonials telling how much better our corn stood up and yielded than corn of their own.

Mr. Kent Campbell, LaHarpe, Ill.

Plymouth, Ill., Dec. 12, 1921.

My Dear Mr. Campbell: The Seed Corn I bought of you and planted in May this year was all and even better than you claimed for it.

It gave entire satisfaction and matured into a fine crop of big, yellow ears.

With kind regards and best wishes, I am

Sincerely yours,

JOHN F. HEDGCOCK.

Mail your order today. We can reach you on any railroad. 


\section{Corn Root Disease Work}

$\mathbf{I}^{\mathrm{N}}$

NVESTIGATION conducted in Illinois during the past fifteen years have shown that corn is affected by several rot diseases of the root, stalk and ear. These rots have been found to be one of the chief causes of thin stands; of large numbers of weak and stunted plants; of stalks that are leaning, down, and broken; of barenness and nubbins; of chaffy, immature ears, and of reduced yields. Realizing the importance of this disease we want to assure our customers that we are doing what we can in this connection to better our corn by conducting a disease-free plot, which was started on our farm last year.

\section{Our Method Recommended.}

Mr. J. R. Holbert, an authority on the production of diseasefree seed corn, recommends picking seed corn early from good, sound stalks and taking care to get the ears having good, sound shanks.

We have been doing this for years, as our friends and customers know. This has helped us develop an excellent strain of corn. Using such seed on the best corn ground in our locality, enables us to produce the finest seed corn; seed corn that will give you more and better corn.

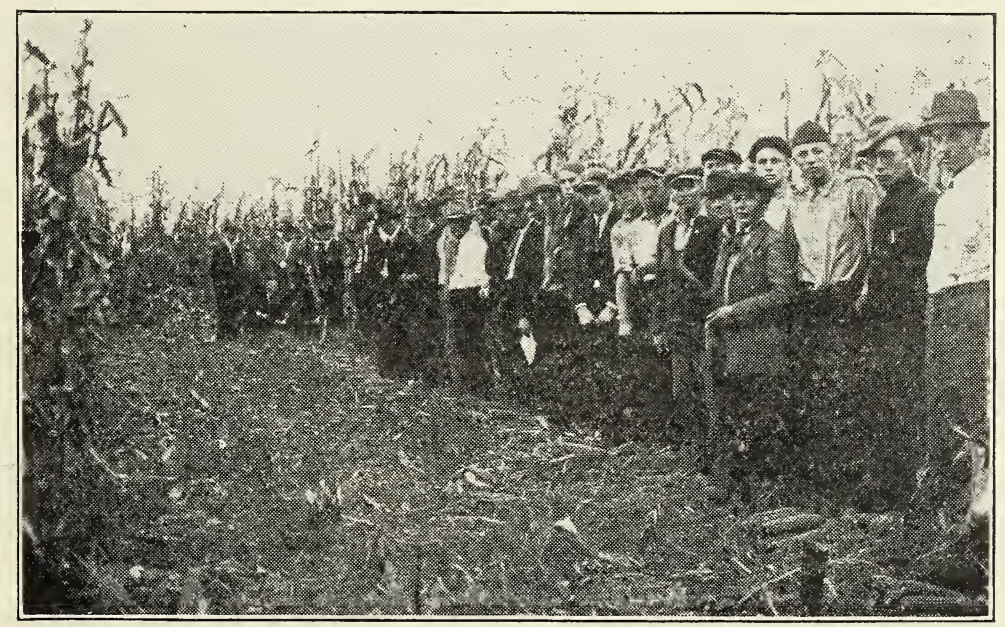

This picture shows the corn in the corn root rot demonstration plots at Kent Campbell's farm, LaHarpe, Illinois. Picture was taken after the meeting on October 5th. 


\section{FIELD SEEDS}

\section{All of Our Seed Complies With the Laws of Illinois.}

\section{THE PURE CLOVER SEED QUESTION.}

CHERE is no bigger question before the farmers right now than that of pure clover seed. The country is rapidly getting filled up with bad weeds, and unless we can call a halt somewhere, it will soon be an impossibility to get really pure clover seed. The trouble is, so many farmers will buy an inferior grade of seed because of a little difference in the price. They think it is all about the same, and one lot is higher because the holder wants more profit. Now, the fact is that the big profits are made on the low-grade seed. It is easier to take seed worth $\$ 6$ wholesale and retail it at $\$ 8$ than it is to take seed worth $\$ 9$ wholesale and retail it at $\$ 10$. Any dealer will tell you so, if you can get him to admit the truth.

\section{MEDIUM RED CLOVER.}

Red Clover was introduced into Pennsylvania about 1770 and is often called June or Medium Clover, the latter term to distinguish it from Mammoth. One of the chief objections to Red Clover is the fact that it winter kills more easily each year. Authorities agree that the increasing tenderness is caused by the continued depletion of the humus. If as much care were used in preparing the seed bed for Red Clover as for Alfalfa, the yields would be wonderfully increased and winter-killing would be lessened. If possible Red Clover seed sown in the early spring should be drilled or harrowed in or covered in some way.

Price and sample on application.

\section{ALSIKE.}

On account of its appearance and growth Alsike Clover was once thought to be a hybrid, between White and Red, but is now known to be a distinct species.

It is particularly adapted to wet soils and thrives on sour soils where the Red will not do so well. Alsike and Timothy ripen about together and the Alsike does not crowd the Timothy as badly as Red Clover does.

A good pasture mixture is 2 parts Timothy, 2 parts Red and 1 part Alsike.

There are approximately 700,000 Alsike seeds to a pound, and 250,000 in a pound of Red Clover, so it takes much less of it.

The Highest Quality Seed is always the cheapest seed. 


\section{TIMOTHY.}

This is a perennial; height, 4 to 5 feet. Too well known to need description. We handle the best home grown seed that we can get. Sow about 10 to 15 pounds per acre.

\section{MAMMOTH CLOVER}

This is a variety of Clover very similar to Medium Red in every respect except size. It is a couple of weeks later and on account of that and its rankness, is not suited to rich land. It is of value on this land. It is said to stand extremes of heat, wet and cold, better than ordinary clover. It generally ranges in price about the same as ordinary clover from $25 \mathrm{c}$ to $50 \mathrm{c}$ per bushel higher.

\section{ALFALFA.}

Alfalfa is a perennial legume producing three crops of hay each year. Prerequisites to successful Alfalfa production are well drained soil, limestone, thorough inoculation and good seed. If you have the first three, we can furnish the seed of first quality.

Price furnished on application.

\section{SWEET CLOVER}

With the present price in favor of it, more Sweet Clover should be sown. No legume is the equal of Sweet Clover for soil improvement. It will grow on any soil but lime must be supplied.

Price. Write or ask for it.

\section{PASTURE MIXTURES.}

A mixture gives a longer period for grazing, furnishes a greater variety, yields a crop richer in protein and makes a better balanced ration than would the grasses composing the mixture if sown separately. But it does not pay to sow in a mixture any grass that will not do well alone. In choosing the grasses to go into the mixture such varieties should be selected that the good qualities of one will balance points in which the other is deficient. A good mixture sown at the rate of 12 pounds per acre is as follows: Red Clover, 5 lbs. Alsike, 2 lbs. Sweet Clover, 2 lbs. Alfalfa, 2 lbs. and Timothy, 1 pound.

Mr. Kent Campbell, LaHarpe, Ill.

Carthage, Ill., Dec. 10, 1921.

Dear Friend: Just received your most welcome letter and was glad to hear from you in regard to the Seed Corn I got from you. It sure was fine. I planted 125 acres of your seed and never had a better stand in my life. It was perfect, and it yielded good and it was satisfactory in every respect, and I thank you very much. You may use my name in advertising your seeds if you so desire. Please send me some samples and prices.

$$
\text { Very truly yours. }
$$

JOHN B. IKERD.

When you sow foul seed, you can expect to harvest foul seed. 


\title{
SOY BEANS
}

\section{Grow More Protein on Your Farms. Plant Soy Beans in Your Corn.}

\begin{abstract}
COY BEANS are being used more each year to plant in corn for $\checkmark$ hogging off and for silage. They decrease the yield of corn very little, and furnish cheap protein feed for hogs. They are a legunie and help build up the soil. Clover is so often a failure that it is necessary to find some legume to take the place of clover. The price of beans is much less than formerly, and it is quite likely an increased acreage of them will be planted this season.
\end{abstract}

\section{OHIO 9035.}

This is one of the best beans developed by the Ohio Expermental station. They are brown in color; matures seed in 120 to 125 days. They are an erect, bushy plant, growing to a height of 30 inches. The leaves are large and is a heavy seed and hay producer. We do not hesitate to recommend this variety.

Write for sample and prices.

\section{MONGOLS.}

This is possibly the best general purpose variety on the market. It is a yellow bean, which matures in about 115 days. The plant grows to a height of about 30 inches, with medium sized stems, and an abundance of foliage, making it an excellent hay variety as well as a heavy yielder of beans. This is a very good variety to plant with corn for hogging off.

Price: Owing to unsettled conditions, we will gladly quote price on application.

\section{SABLE.}

The Sable is a black bean, and is a remarkably good dual purpose bean. The plants stand erect and seldom lodge, making it a good yielder, is adaptable for hogging off as well.

Ask or write for price and sample.

\section{MORSE.}

Light green or olive. A heavy yielder. Matures in about 115 days, growing to a height of 30 inches. It pods very close to the ground, which makes it less desirable for silage, but a very good bean for hogging down or hay.

Write for prices.

We do not substitute. If we haven't what you order, your money is refunded. 


\section{DWARF ESSEX RAPE.}

If you are a hog or sheep raiser, you should by all means use rape. Experiments show it is equal to clover as a forage crop for hogs. It is so well known that a further description is not necessary.

Prices quoted on application.

\section{SUDAN GRASS AND MILLET.}

For late sowing to replace other crops, Millet and Sudan Grass make excellent hay crops.

Prices quoted on application.

\section{IOWA 103 OATS.}

Have you ever tried Iowa 103 Early Oats? It is one of the best all-around varieties we have ever used or seen. It is especially good on rich land, as it does not grow a rank straw.

It is an exceptional yielder, outranking all other varieties in the Hancock County Farm Bureau tests for several years past. They mature at a time that permits early harvest and threshing. They are particularly good if you seed clover in your oats, as they come off early enough to almost always insure your stand of clover. Iowa 103 is the variety of oats that yielded 93 bushels per acre on our farm. This is a very popular and widely grown variety thruout the corn belt.

\section{IOWAR OATS.}

Iowar Oats is a variety developed by the Iowa Experiment Station in 1918. They are about a week later in maturing than Sowa 103. In yield they rank about equal. These two variecies, both originating in Iowa, are probably the most popular ana widely grown oats in Illinois. We secured our first seed of Iowar direct from the Iowa Experiment Station. It is true to type and name and is of the highest quality.

Mr. Kent Campbell.

LaHarpe, Ill.

Bowen, Ill.. Dec. 12, 1921.

Dear Sir: We are more than pleased with the results obtained from using your seed corn the past two years. We planted the Reid's Yellow Dent. It stood up well dspite the fact that most all the corn in this section was blown down. One field made a yield of 75 bushels per acre. Which, I believe, is as large a yield, if not the largest, in this neighborhood.

Will you please quote us prices on Red Clover Seed and on Yellow Dent Corn for this coming season. We will be in the market for Clover seed and Seed Corn this spring.

Yours respectfully,

O. GILMORE HOUGH. 


\section{Co-operative Wheat Seeding Work}

$\mathrm{O}$

$\mathrm{N}$ our farm, where we grow most of our seed corn, we are also carrying out a series of wheat seeding demonstrations. This wheat seeding work is co-operative with the State Department of Entomology and the Hancock County Farm Bureau. The object of these demonstrations is to show the best time to sow fall wheat to avoid the damage by Hessian fly. We have one of the eight wheat demonstration fields in Illinois.

This season our first plot was seeded on September 10, our last plot October 5. Other dates of seeding were Sept. 15, 20, 25, and 30. All the plots seeded before Sept. 25 were infested with the Hessian fly. The earlier seeded plots very badly infsted.

Mr. W. P. Flint, state field entomologist, has charge of this demonstration.

Our yield of Turkey Red wheat in 1919 was 48 bushels per acre. In 1920 it was 31 bushels per acre, and in 1921 it was 32 bushels per acre. Our yield of Kanred wheat in 1921 was 37 bushels per acre.

We have Turkey Red and Kanred seed wheat for sale at the proper season. Get some for this fall's seeding.

\section{TURKEY 10-110.}

At the proper season we have the Turkey $10-110$ seed wheat for sale, certified by the Illinois Crop Improvement Association. This is an improved strain of the Turkey Red developed by the Illinois Experiment Station at Urbana, Ill.

\section{KANRED.}

The Kanred wheat is a new wheat developed by the Kansas Experiment Station from the Turkey Red. It is becoming very popular. Some of the good qualities claimed for it are, it ripens two or three days earlier than the Turkey, has a stiffer straw and does not lodge so early when it becomes over-ripe. We have this seed for sale at the proper season, certified by the Illinois Crop Improvement Association.

Mr. Kent Campbell,

Carthage, Ill., Dec. 12, 1921.

LaHarpe, Ill.

Dear Sir: I am very well pleased with the Seed Corn I purchased of you last spring. I believe it averaged pretty close to $100 \%$ germination, and I am inclined to believe that the excellent seed was directly responsible for the fact that I raised more corn this year than I have ever raised before, and it was good quality, considering the season.

The corn was everything and more than I expected. Thanking you, I am, Yours respectfully,

HENRY S. LONG, Carthage, Ill. 


\section{Testimonials}

Mr. Kent Campbell,

LaHarpe, Ill.

Spickard, Mo. Nov. 10, 1921.

Dear Sir: I was very well pleased with my corn I purchased from you last spring. I received a good yield and picked several bushels of the best seed I ever raised. This seed was hand-picked from the field. I believe that the extra yield I got from using your seed in place of my own, more than paid for the cost of the seed I bought of you. Several of my neighbors have asked me to save them seed for the coming year.

Please send to me your prices on the same corn for next year, and also clover and Soy Bean seed. I would like to have some samples of your clover and soy beans if you send them out. Also I would like some information on soy beans as to the best kind to us, when to plant and the best way to plant in corn. Also what they usually yield when sowed to themselves, and the best way and time to do this.

Thanking you in advance I am, Yours truly,

W. E. ROBBINS.

Mr. Kent Campbell,

LaHarpe, Ill.

Niota, Ill., Dec. 12, 1921.

Dear Sir: I received four and one-half bushels of Reid's Yellow Dent Seed Corn of you last spring, and am so well pleased with the results that I would like very much to have your prices for next spring, as I expect to order more. Yours respectfully,

BEN SIEGRIST.

Mr. Kent Campbell,

LaHarpe, Ill.

Dear Sir: The Seed Corn I purchased of you was above my expectations in every way, and you may rest assured that if I'm ever in a position to do you a favor, I'll be glad to do it. The corn yielded a little over 78 bushels per acre. My Kanred wheat is coming right along also.

Yours very truly,

FRANK FELLHEIMER Macomb, Ill.

Mr. Kent Campbell,

LaHarpe, Ill.

Niota, Ill.: Dec. 12, 1921.

Dear Sir: Your Seed Corn was all right, came well and made a good crop of corn. Had one piece that weighed out seventy-six bushels. May want clover seed and some Soy Beans for next spring. Yours truly,

Mr. Kent Campbell, LaHarpe, Ill.

Dear Sir: The Soy Beans I got of you were fine. Got a good crop of both corn and beans. The corn I think is of excellent variety and the beans are a splendid variety for yield.

W. G. POMROY, Warsaw, Ill.

Mr. Kent Campbell,

LaHarpe, Ill.

Dear Sir: I had very poor luck with my corn crop this season, owing to a terrific hail storm, drought and wet fall. I intended picking my seed out of this field, but there was not one ear fit for same. Now I do not blame the seed at all. No doubt, I would have had a good crop if condition had been favorable. I am hoping for success next time, and if in need of Seed Corn will forward you my orders.

Yours truly,

R. R. PATTON, Warsaw, Ill.

All of our seed corn is in the house early. 


\section{ORDER BLANK}

\section{KENT CAMPBELL, LaHarpe, Ill.}

\section{PURE BRED SEED CORN}

\section{Date line.}

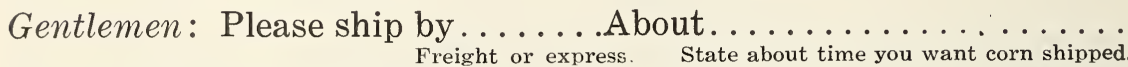
the Seed Corn listed below. I enclose.............. Dollars

Name . .

Post Office

Freight Station If different from P. O.

County.
State.......

R. F. D
Amount Enclosed P. O. Order $\$ \ldots . .$. Check $\$ \ldots . .$. Bank Draft $\$ \ldots . .$. Ex. M. O. $\$$..... Cash

\section{SACK PICKED, RACK DRIED}

(Sh. ) Bus. Imp. Reid's Yellow Dent.... @ \$3.00

(Ear) Bus. Imp. Reid's Yellow Dent.....@ $\$ 3.50$

(Sh.) Bus. Gold Standard Leaming.... @ \$3.00

(Ear) Bus. Gold Standard Leaming.....@ \$3.50

(Sh. ) Bus. Boone Co. White...........@ $\$ 3.00$

(Ear) Bus. Boone Co. White..........@ $\$ 3.50$

(Sh. ) Bus. Early Yellow...........@@ $\$ 3.00$

(Ear) Bus. Early Yellow............@ \$3.50

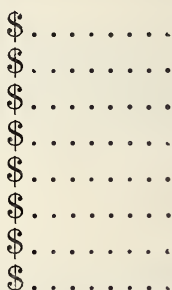

REGULAR STOCK SELECTED AT EARLY HUSKING TIME

......(Sh. ) Bus. Imp. Reid's Yellow Dent....@@ $\$ 2.50$

(Sh.) Bus. Boone County White.......@ $\$ 2.50$

....... (Sh. ) Bus. Early Yellow ............@ \$2.50

...........Bus. Iowa 103 Oats..........@@.....

.............. Soy Beans, kind.........@ \$....\$.

............. Clover Seed, kind........@@ $\$$.....

.Bus. Timothy .............@@ .

.Lbs. Rape ...............@

$\$$.

$\$$...

$\$ \ldots \ldots$

$\$$.

S.

3.

$\$$.

$\$$.

$\$$.

Total Amount

$\$ \ldots \ldots$

Please give us names of a few farmers who may want Seed Corn 


\section{What You Want to Know}

Location-LaHarpe is on the main line of the Toledo, Peoria and Western R. R. ; 28 miles east of Keokuk, Iowa; 18 miles southeast of Burlington, Iowa, and 84 miles west of Peoria.

The Seed House is on the farm in the city limits, just three-quarters of a mile south of the public school building in LaHarpe.

Terms-Our terms are Cash with the order. You may remit by check, draft or money order.

Orders-Are acknowledged the same day they are received and shipment made prcmetly unless otherwise instructed. Careful attention paid to small orders as well as large ones. Orders received at planting time are handled with the least possible delay.

Your Seed Free-Anyone can have his seed free if he can prove that we do not handle our seed exactly as we claim. It is only by honest dealing that we have the trade and confidence of the people. Could we afford to jeopardize our reputation by using questionable methods in handling our seed corn? You take no chances, for you are given twelve days to examine and test a shipment, and if not satisfied with the corn you can return it and your money will be refunded. Could an offer be fairer?

Railroad Fare-We will pay railroad fare and other expenses to any one not more than 50 miles away who comes to us and buys 50 bushels of corn, or who comes and does not find our corn or methods of handling is exactly as we represent them.

Reliability-We refer you to the LaHarpe State Bank or the First National Bank of LaHarpe; also R. G. Dun's Mercantile Agency, or you can have your banker look up our standing.

Telephone-You can reach us by telephone through the LaHarpe central. Long distance connection.

Shipment-By freight, unless instructed otherwise.

Prices-Are f. o. b. LaHarpe, Illinois.

Ear corn, 70 pounds per bushel net.

Shelled corn, 56 pounds per bushel net.

Bags and crates free with corn.

Write plainly.

KENT CAMPBELL, LaHarpe, Iìinois. 


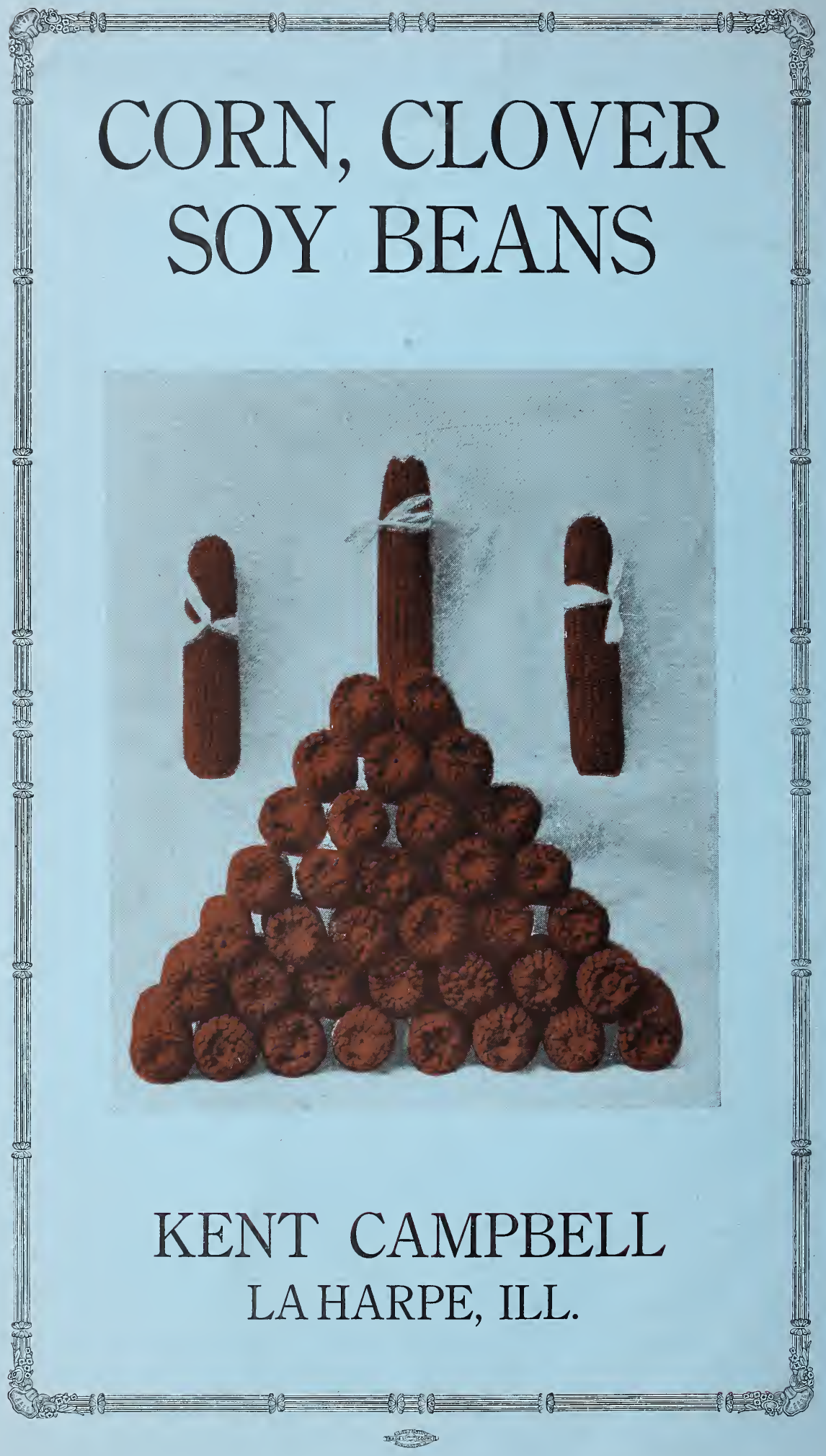

